Кочергіна Ірина

кандидат психологічних наук, асистент кафедри психології філософського факультету

Львівського національного університету імені Івана Франка https://orcid.org/0000-0002-8699-0601

DOI https://doi.org/10.35619/praprv.v1i15.188

\title{
САМОРЕГУЛЯЦІЯ ПОВЕДІНКИ ТА ДІЯЛЬНОСТІ ОСОБИСТОСТІ В УМОВАХ КАРАНТИНУ
}

\begin{abstract}
Анотація. $У$ статті висвітлено результати дослідження особливостей саморегулящії поведінки та діяльності особистості в умовах карантину. Описано важливість наукових досліджень щзодо впливу карантину на психічний стан людини. Проаналізовано існуючі дослідження щзодо особливостей взаємодії сімей в умовах карантину, впливу негативних емоційних переживань на психічне здоров'я особистості. Показано, щзо зниження сочіальної активності людей, постійне хвилювання та тривога, обмеження спілкування, виступають стресогенними чинниками в умовах карантину. Наголошено, щзо важливим $\epsilon$ вміння управляти власним психічним станом задля ефективного планування та організації власної діяльності. Підкреслено, щуо особи, які внаслідок посилення карантинних заходів втратили роботу, або тимчасово не мали змоги працювати характеризуються нижчою здатністю до планування поведінки та діяльності, мають недостатньо чітке уявлення щзодо власного майбутнього, в них порушений процес постановки цілей, мають нижчий рівень потреби усвідомленому плануванні та програмуванні своєї поведінки, в даний момент життя є більш залежними від ситуації та думки інших людей. Стверджується, щчо в осіб, які внаслідок карантину втратили роботу, спостерігається нижчий рівень самоприйняття, щэо вказує на деяку незадоволеність собою, розчарування у власних силах та стурбованість щзодо власних можливостей.
\end{abstract}

Ключові слова: саморегуляція, поведінка, планування, карантин.

Постановка проблеми. У березні 2020 року враховуючи поширеність та тяжкість перебігу гострого респіраторного захворювання SARS-CoV-2 Всесвітня організація охорони здоров'я визнала його пандемією. Багато країн ввели карантинні обмеження у вигляді обмеження руху людей для запобігання поширеності захворювання. В Україні також був введений загальнонаціональний карантин. Разом 3 тим зростає потреба у наукових дослідженнях щодо впливу карантину на психічний стан людини.

Дослідники зазначають, що спалах захворюваності має вплив на психічне життя людини (Длугош, Кривачук, 2020). Особливе значення має той факт, що це перша пандемія в історії людства, коли дані про поширеність захворювання, його симптоми та наслідки відразу поширюються мережею Інтернет. Відповідно, паніка, тривога, напруга та страх поширюються значно швидше (Чабан, Хаустова, 2020). Зазначається, що карантин та обмеження соціальної активності впливають на емоційний стан людини, зростає кількість негативних емоційних переживань, що, в свою чергу негативно впливає на психічне та фізичне здоров'я (Макаренко, 2020).

Зниження соціальної активності людей, постійне хвилювання та тривога, обмеження спілкування, безперечно, виступають стресогенними чинниками в умовах карантину, тому необхідним $\epsilon$ вміння управляти власним психічним станом задля ефективного планування та організації власної діяльності, побудови гармонійних стосунків з навколишніми тощо. Такий аспект особистості сьогодні $\epsilon$ маловивченим, а проблематика особливостей саморегулятивних вмінь та навичок в умовах обмеження соціальної активності людей 
залишається відкритою. В той же час, саморегуляція виступає внутрішньою цілеспрямованою активністю людини, в якій прослідковується єдність та цілісність свідомості людини. Проявляється саморегуляція у здатності до адекватного реагування в соціальній ситуації, що полягає у вмінні відповідати соціальним вимогам, демонструвати соціально прийняту поведінку без зовнішнього контролю, вмінні стримати свої дії чи змусити себе до них. Окрім цього, вміння особи керувати своїм психічним станом $\epsilon$ запорукою збереження психічного здоров'я, здатності гармонійно співіснувати з іншими людьми і навколишнім світом та успішно вирішувати життєві проблеми.

Аналіз останніх досліджень 3 проблеми. Разом 3 появою хвороби SARS-CoV-2 та обмеженнями, які 3 нею пов'язані виникають нові особливості життєдіяльності. Тому науковці продовжують досліджувати особливості психологічного впливу карантину. Багато дослідників сходяться на думці, що зміна способу життя внаслідок появи нового коронавірусу значним чином впливає на психічний стан особистості.

В умовах загрози здоров’ю, економічної нестабільності, обмеження соціальної активності багато людей змушені були адаптуватись до нової організації свого життя та дистанційної роботи. Дослідження особливостей адаптації сімей до карантинних обмежень здійснено Галецькою, Кліманською, Перун. Авторками виявлено неоднозначність впливу карантину на сімейну ситуацію: від зближення та поглиблення емоційних стосунків між членами сім'ї до погіршення стосунків. У взаєминах з дітьми простежувались дві тенденції: поглиблення стосунків та втрата терпіння. Виокремлено три типи реагування на ситуацію карантину: резильєнтність, дистрес та стабільність.

Багато дослідників зосередились на дослідження емоційного стану осіб. Зокрема, Н. Макаренко здійснено аналіз наслідків тривалого локдауну, а саме тривоги, стресу, агресивності, емоційного виснаження. Авторкою описано результати синдромів професійного вигорання вчителів до карантину та рівень емоційного вигорання після повернення до роботи. А також проаналізовано необхідність проведення тренінгових занять для зниження рівня емоційного виснаження (Макаренко, 2020). Дослідження наслідків карантину на молодь здійснено Дуглошем та Кривачук. Автори вивчали нейротизм студентів. Проведене дослідження дає підстави стверджувати, що головними чинниками, які впливали на рівень нейротизму серед студентів були навчальне вигорання, стать, економічна ситуація, зацікавленість пандемією та задоволеність життям. Вказується, що нейротизм зростав водночас із навчальним вигоранням, втратою економічних ресурсів та підвищенням зацікавленості пандемією. Вищий рівень нейротизму простежувався у жінок.

Аносова звертає особливу увагу на саморегуляцію особистості в умовах соціальної ізоляції. Авторкою зазначається, що саморегуляція психоемоційної сфери $\epsilon$ одним 3 найважливіших завдань для людини для збереження внутрішньої рівноваги і психічного здоров'я особистості (Аносова, 2020).

На значення емоційної саморегуляції звертається увага Полі. Наголошується, що психологічний вплив карантину простежується у порушенні емоційної саморегуляції, здатності оптимізувати власний емоційний стан, керувати емоціями, почуттями та діяльністю з врахуванням актуального емоційного стану (Poli, Conversano, Gemignani, 2020).

Мета статті. Дослідити особливості саморегуляції поведінки та діяльності особистості в умовах адаптивного карантину в Україні.

Виклад основного матеріалу дослідження. Для досягнення поставленої мети було проведено дослідження за участю 132 осіб різного віку та статі. Дослідження проводилось протягом жовтня 2020 року в умовах карантину, пов'язаного з поширенням захворювання COVID-19.

Для вивчення особливостей саморегуляції поведінки та діяльності особистості були використані такі методики: методика «Стиль саморегуляції поведінки» В. Моросанової, а також опитувальник «Шкали психологічного благополуччя» К. Ріфф в адаптації Т. Шевелєнкової і П. Фесенка. Окрім того, досліджуваним пропонувалась анкета, у якій їх просили вказати чи змінився їх режим життя під час карантину, а саме чи, можливо, вони 
втратили роботу, чи продовжували працювати у звичному режимі, або у дистанційному форматі, чи зменшилась їх соціальна активність тощо.

Для виявлення особливостей саморегуляції поведінки та діяльності особистості, було проаналізовано статистичні показники порівняльного та кореляційного аналізів.

За допомогою порівняльного аналізу виявлено відмінності у двох групах осіб: тих, чий режим та стиль повсякденного життя вимушено зазнав змін у зв'язку з карантином та тих осіб, які зазначили, що карантин не вплинув на їх повсякденне життя. На основі порівняльного аналізу за допомогою Т-тесту встановлено, що в тих осіб, у яких змінився режим життя під час карантину (тобто в тих осіб, які зазначали, що втратили роботу чи тимчасово не працювали) є нижчими показники планування ( $\mathrm{p}=0,000)$, оцінки результатів $(\mathrm{p}=0,000)$, саморегуляції ( $\mathrm{p}=0,001)$ та управління середовищем $(\mathrm{p}=0,000)$ (рис.1).

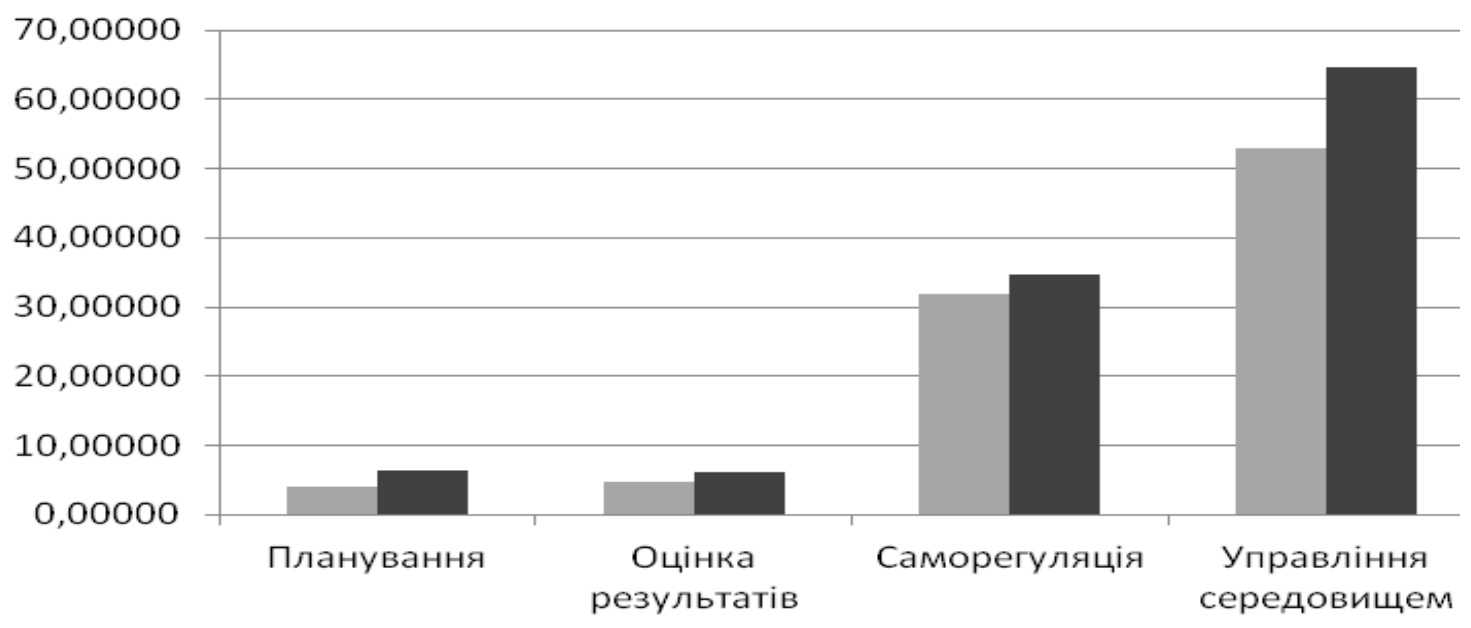

Стиль життя змінився

Стиль життя не змінився

Рис. 1. Порівняння показників саморегуляції поведінки та діяльності осіб, в яких змінився режим життя під час карантину та тих осіб, у яких режим життя не змінився

Тому, можемо зробити висновок, що особи, які внаслідок посилення карантинних заходів у країні втратили роботу, або тимчасово не мали змоги працювати характеризуються нижчою здатністю до планування поведінки та діяльності, мають недостатньо чітке уявлення щодо власного майбутнього, в них порушений процес постановки цілей, які можуть бути нечіткими та малоусвідомленими. Окрім того, вони мають більше труднощів з оцінкою себе та результатів своєї діяльності і поведінки. Тобто, особи, в яких змінився режим життя під час карантину більшою мірою, аніж ті, хто кардинально не змінив режим життя, мають труднощі з організацією власною діяльності з врахуванням кінцевої мети. За отриманими даними кореляційного аналізу встановлено зв'язок між оцінкою результатів діяльності та самоприйняттям в групі осіб, які змінили режим життя $(\mathrm{r}=0,29)$. Тобто, зберігаючи позитивне ставлення до себе можливе більш стійке формування стійкості суб'єктивних критеріїв стійкості оцінки результатів власної діяльності.

Також, особи, в яких змінився режим життя під час карантину характеризуються нижчим рівнем саморегуляції. Тобто, вони мають нижчий рівень потреби усвідомленому плануванні та програмуванні своєї поведінки, в даний момент життя є більш залежними від ситуації та думки інших людей. У цих досліджуваних знижена можливість компенсації неблагополучних для досягнення поставленої цілі особистісних особливостей, у порівнянні 3 особами, чий режим життя під карантину не змінився. Відповідно, вони можуть мати більше труднощів у постановці цілей та формуванні плану майбутньої діяльності. Загалом, потреба у плануванні знижена. Цікавими є кореляції між саморегуляцією та показниками позитивних стосунків з іншими у групі осіб, які зазначали про зміну стилю життя під час карантину. Так, ïx саморегуляція пов'язана 3 позитивними стосунками 3 іншими людьми $(\mathrm{r}=0,33)$ та здатністю до управління середовищем $(\mathrm{r}=0,34)$. В групі осіб, чий режим життя під час 
карантину не змінився таких кореляцій не спостерігається. Тобто, для осіб, які під час карантину втратили роботу, або змушені були тимчасово не працювати для збереження позитивної віри у себе та свої можливості є важливими близькі, приємні, довірливі відносини 3 іншими людьми, можливість відчути та проявляти турботу. А також зростання здатності до саморегуляції поведінки пов'язане із зростанням впевненості і компетентності в управлінні повсякденними справами, вмінням обирати та створювати умови, які б задовольняли власні потреби та цілі. Водночас, здатність до управління середовищем в осіб, яких змінився режим життя під час карантину є нижчою, аніж в осіб, які не зазначали про зміну їх стилю життя. Тобто, при зміні режиму дня та основного виду зайнятості можлива поява почуття нездатності зарадити чи покращити умови життя, з'являється безпорадність та безсилля в управлінні зовнішнім середовищем.

У осіб, чий режим та стиль життя не змінився спостерігаються взаємозв'язки між управлінням середовищем та автономією $(\mathrm{r}=0,28)$ та особистісним зростанням $(\mathrm{r}=0,33)$. В той час, як у групі осіб, чий режим життя змінився таких кореляцій не спостерігається (таблиця 1).

Табличя 1

Кореляцї̈ міэн показником управління середовищем та особистісними особливостями $(p \unlhd 0,05)$

\begin{tabular}{|l||c|c|}
\hline \multicolumn{1}{|c|}{ Група } & $\begin{array}{c}\text { Особи, у яких не змінився } \\
\text { режим життя }\end{array}$ & $\begin{array}{c}\text { Особи, у яких режим життя } \\
\text { змінився }\end{array}$ \\
\hline $\begin{array}{l}\text { Особистісні } \\
\text { особливості }\end{array}$ & $\mathbf{0 , 2 7}$ & $\mathbf{0 , 3 4}$ \\
\hline $\begin{array}{l}\text { Позитивні стосунки 3 } \\
\text { іншими }\end{array}$ & $\mathbf{0 , 2 8}$ & 0,13 \\
\hline Автономія & $\mathbf{0 , 3 3}$ & 0,15 \\
\hline Особистісне зростання & $\mathbf{0 , 4 8}$ & $\mathbf{0 , 3 3}$ \\
\hline Самоприйняття & \multicolumn{2}{|c|}{} \\
\hline
\end{tabular}

На підставі цього можна стверджувати, що здатність протистояти тиску оточення та навколишнім змінам, відчуття саморозвитку пов'язані із здатністю регулювати власну поведінку та впевненістю в управлінні повсякденними справами.

Спільними кореляціями у двох групах є зв'язок між управлінням середовищем та позитивними стосунками 3 іншими, а також самоприйняттям. Тобто, для збереження здатності ефективно використовувати різні життєві обставини, гнучко реагувати на зміни навколишнього середовища важливими $є$ добрі та близькі стосунки 3 іншими людьми, а також підтримка позитивного ставлення до себе.

Окрім цього, застосовано однофакторний дисперсійний аналіз, що дало змогу виокремити шкали, за якими наявні статистично значущі відмінності групових показників. На основі цього був здійснений порівняльний аналіз групових показників за критерієм Шеффе, в результаті виявлено статистично значущі відмінності у особливостях саморегуляції поведінки та діяльності тих осіб, які вказали, що карантин ніяк не позначився на їх житті, тих осіб, які почали працювати дистанційно, тих, які тимчасово були без роботи при загальному збереженні місця праці, та тих осіб, які повністю втратили роботу.

Аналіз змінних та однофакторний дисперсійний аналіз за критерієм Шеффе при $\mathrm{p}<0,05$ (рис. 2), вказують на вагомі відмінності між підгрупами за такими показниками: планування $(p=0,015)$, саморегуляція $(p=0,008)$, цілі в житті $(p=0,000)$, самоприйняття $(\mathrm{p}=0,000)$. 


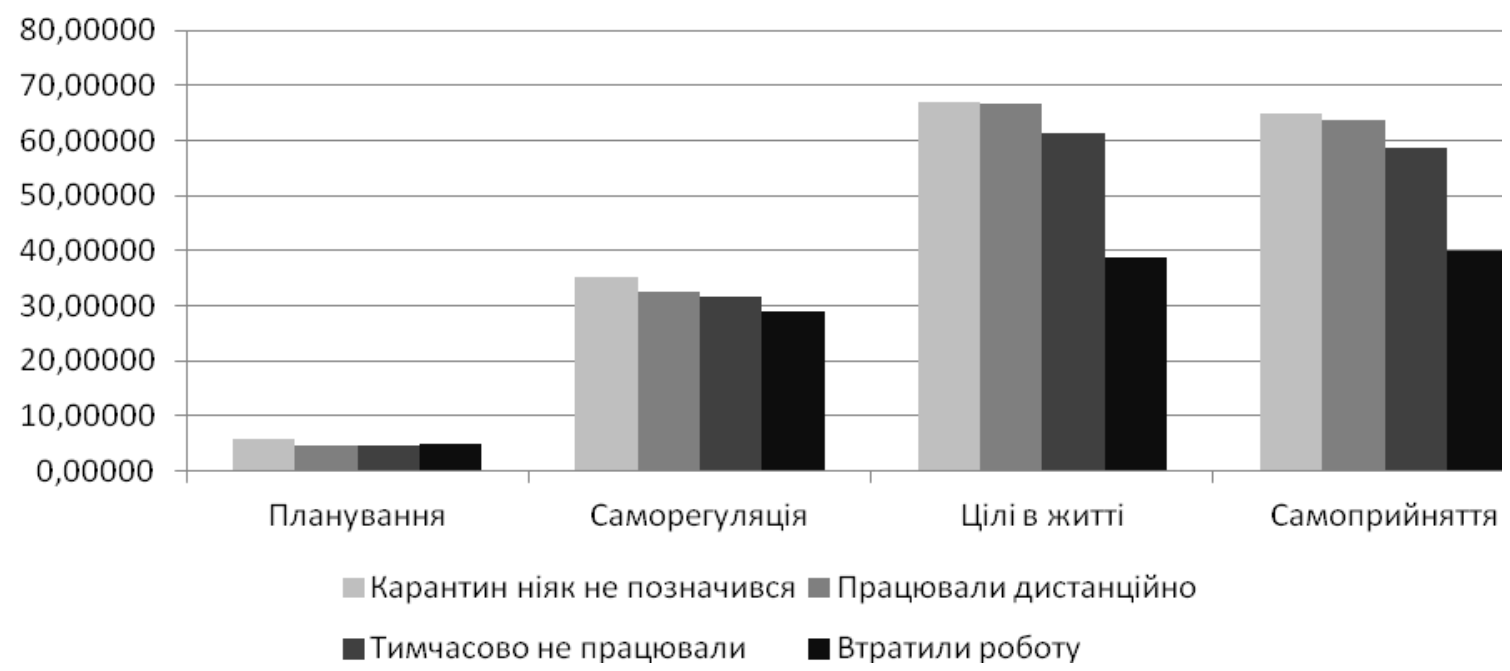

Рис. 2. Порівняння показників саморегуляції поведінки та діяльності в групах осіб із різним типом трудової діяльності у період карантину

Як видно із рисунка 2, найвищими показники саморегуляції поведінки та діяльності є в тих осіб на життя яких введення карантину не вплинуло. Вони продовжили жити та працювати у звичному режимі, як і до карантину. Найнижчими ці показники є групі осіб, які внаслідок карантину повністю втратили роботу та змушені були якісно по-новому адаптувати своє життя до нових реалій. Для них, а також для осіб, які тимчасово змушені були не працювати характерними $\epsilon$ нижчий показник планування, що пов'язано із труднощами передбаченням власного майбутнього, невпевненістю та ситуативністю в постановці цілей, труднощами в реалістичній оцінці майбутнього. В осіб, які втратили роботу спостерігається нижчий показник саморегуляції, що вказує на залежність у регуляції власної поведінки та діяльності від ситуації. Можлива поява ситуативності та непостійності у планах та цілях, відсутність довгострокового планування, слабша самоорганізація діяльності. Можливі труднощі в адаптації до нових умов в ситуації невизначеності та розмитості майбутнього. За показником цілей в житті нижчі значення також спостерігались в групі осіб, які повністю втратили роботу, що вказує на зниження відчуття зв'язку між сьогоденням та майбутнім. Також, у цій досліджуваній групі спостерігається нижчий рівень самоприйняття, що вказує на деяку незадоволеність собою, розчарування у власних силах та стурбованість щодо власних можливостей.

Тобто, особи, які внаслідок карантину повністю втратили роботу та були змушені гнучко та швидко реагувати на нові обставини життя, у порівняні 3 особами, які продовжували працювати у звичному режимі, перейшли у формат дистанційної роботи, або тимчасово не працювали деякий період характеризуються стурбованістю власними можливостями розвитку, здатністю покращити або змінити умови та режим свого життя, мають нижчий рівень стійкості до соціального впливу та думки інших людей.

Висновки і перспективи подальших розвідок. Можемо підсумувати, що різкі зміни у повсякденному житті, які відбулись в житті українців у зв'язку з поширенням захворюванням та вимушеною соціальною ізоляцією позначились на особливостях саморегуляції поведінки та діяльності. Оскільки карантинні обмеження вплинули не лише на особисті контакти людей, але й на їх звичний режим життя, що в умовах нестабільного економічного розвитку країни привело до втрати роботи певною частиною осіб. Відповідно, це не могло не позначитись на психічному житті особистості.

Аналізуючи погляди вчених на особливості переживання соціальної ізоляції, можна підсумувати, що в умовах карантину та непередбачуваності майбутнього зростають такі негативні емоційні стани як тривога, напруга, страх. Ситуація, яка складається у світі ставить перед людиною нові виклики, відповідно змінюються особливості саморегуляції поведінки та діяльності особистості. 
Встановлені у дослідженні дані підтверджують, що особи, які втратили роботу внаслідок карантину, або тимчасово не працювали характеризуються нижчою здатністю до планування та організації власної діяльності, самоконтролю поведінки, аніж особи, які продовжили працювати. У них нижчий рівень саморегуляції, тобто вони є більш залежними від ситуації та рішень інших людей.

Отримані дані дають підстави стверджувати, що саморегуляція поведінки та діяльності пов'язана 3 тими змінами та обмеженнями, які відбуваються у світі. В подальшому, зважаючи на те, що пандемія триває, продовжуючи залишатись серйозним стресогенним чинником для населення, важливим $є$ проведення подальших досліджень саморегуляції поведінки та діяльності зважаючи на особливості емоційної сфери особистості та обмеження кола соціальної взаємодії.

\section{СПИСОК ПОСИЛАНЬ}

Аносова, А. В. (2020). Особливості самоусвідомлення і саморегуляції дорослої людини в умовах пандемії. В Матеріали XIV Міжнародної науково-практичної онлайнконферениії з організаційної та економічної психологї (с. 22-25). Київ: Біла Церква.

Галецька, I. I., Кліманська, М. Б., \& Перун, М. Б. (2020). COVID-19, локдаун та життя сімї у новій реальності. Психологічний часопис, 6 (9), 40-57.

Длугош, П., Кривачук, Л. (2020). Молодь Польщі та України в умовах пандемії COVID-19: стан психічного здоров’я та рівень нейротизму. Психологічний часопис, 6 (7), 9-17.

Макаренко, Н. М. (2020). Зниження пост-карантинного емоційного вигорання методами ізотерапії. Психологічний часопис, 6 (10), 9-16.

Чабан, О. С., \& Хаустова, О. О. (2020). Психічне здоров'я в період пандемії COVID-19 (особливості психологічної кризи, тривоги, страху та тривожних розладів). НейроNews: психоневрологія та нейропсихіатрія, 3 (114), 26-36.

Poli, A., Conversano, C. \& Gemignani, A. (2020). The psychological impact of SARS-CoV-2 quarantine: observations through the lens of the polyvagal theory. Pisa: Clinical Neuropsychiatry.

\section{REFERENCES}

Anosova, A. V. (2020). Osoblyvosti samousvidomlennia i samorehuliatsii dorosloi liudyny v umovakh pandemii [Features of self-awareness and self-regulation of an adult in a pandemic]. V Materialy XIV Mizhnarodnoi naukovo-praktychnoi onlain-konferentsii $z$ orhanizatsiinoi ta ekonomichnoi psykholohii (s. 22-25). Kyiv: Bila Tserkva. [in Ukrainian].

Haletska, I., Klimanska, M., \& Perun, M. (2020). COVID-19, Lokdaun ta zhyttia simi u novii realnosti [COVID-19, lock-down and family life in a new reality]. Psykholohichnyi chasopys, 6 (9), 40-57. [in Ukrainian].

Dluhosh, P. Kryvachuk, L. (2020). Molod Polshchi ta Ukrainy v umovakh pandemii COVID-19: stan psykhichnoho zdorovia ta riven neirotyzmu [Youth of Poland and Ukraine in the context of the COVID-19 pandemic: mental health and neuroticism]. Psykholohichnyi chasopys, 6 (7), 9-17. [in Ukrainian].

Makarenko, N. M. (2020). Znyzhennia post-karantynnoho emotsiinoho vyhorannia metodamy izoterapii [The reduction of post-quarantine emotional burnout by visual art therapy].

Psykholohichnyi chasopys, 6 (10), 9-16. [in Ukrainian].

Chaban, O. S., \& Khaustova, O. O. (2020). Psykhichne zdorovia v period pandemii COVID-19 (osoblyvosti psykholohichnoi kryzy tryvohy strakhu ta tryvozhnykh rozladiv) [Mental health during the COVID-19 pandemic (features of psychological crisis, anxiety, fear and anxiety disorders)]. NeiroNews Psykhonevrolohiia Ta Neiropsykhiatriia, 3 (114), 26-36. [in Ukrainian].

Poli, A., Conversano, C. \& Gemignani, A. (2020). The psychological impact of SARS-CoV-2 quarantine: observations through the lens of the polyvagal theory. Pisa: Clinical Neuropsychiatry. [in English]. 


\title{
SELF-REGULATION OF BEHAVIOR AND ACTIVITIES OF PERSONALITY UNDER QUARANTINE
}

\author{
Kocherhina Iryna \\ Candidate of Psychological Sciences, \\ Lecturer at the Department of Psychology \\ Faculty of Philosophy \\ Ivan Franko National University of Lviv \\ https://orcid.org/0000-0002-8699-0601 \\ DOI https://doi.org/10.35619/praprv.v1i15.188
}

\begin{abstract}
The features of self-regulation of behaviour and activity of the person in the conditions of quarantine are presented in the article. The importance of scientific research on the impact of quarantine on the mental state of man is described. Existing research on the peculiarities of family interaction in quarantine, the impact of negative emotional experiences on the mental health of the individual is analysed here. It is shown that the decrease in social activity of people, constant anxiety and worry, limited communication, are stressful factors in quarantine. It is emphasized that the ability to manage own mental state is important for the effective planning and organization of own activity.

It is emphasized that persons who have lost their jobs or temporarily unable to work due to increased quarantine measures are characterized by lower ability to plan behaviour and activities, do not have a clear idea of their own future, have impaired goal setting, have a lower need for conscious planning and programming their behaviour at this point in life are more dependent on the situation and opinions of other people. It is claimed that people who have lost their jobs as a result of quarantine have a lower level of self-acceptance, which indicates some dissatisfaction with themselves, frustration with their own abilities and concerns about their own capabilities. It has been established that persons who have completely lost their jobs as a result of quarantine and were forced to respond flexibly and quickly to new life circumstances, compared to individuals who continued to work as usual, switched to the format of remote work, or temporarily not working for some time characterized by concern for their own opportunities for development, the ability to improve or change the conditions and mode of their life, have a lower level of resilience to social influence and other people's opinions.
\end{abstract}

Key words: self-regulation, behaviour, planning, quarantine.

Стаття надійшла до редакиії 25.11.2020 p. 